\title{
IMPLEMENTACIJA MEĐUNARODNOG HUMANITARNOG PRAVA U PRAVNI SISTEM BOSNE I HERCEGOVINE
}

Sažetak: Rad se bavi pitanjem implementacije normi međunarodnog humanitarnog prava u pravni sistem Bosne i Hercegovine, kao i načinom na koji se ta implementacija vrši, uz obradu pojedinih instituta medunarodnog humanitarnog prava u krivičnom zakonodavstvu Bosne i Hercegovine.

Autorica u radu obrađuje najvažnije principe međunarodnog humanitarnog prava, od principa zabrane retroaktivne primjene krivičnopravnih normi i univerzalne jurisdikcije, preko pitanja zaštite pojedinih kategorija lica i dobara, upotrebe zaštitnih znakova u oružanom sukobu, pa do koncepta krivične odgovornosti pojedinaca $u$ svojstvu nadređenog (komandne odgovornosti), kao i za odbijanje izvršenja naređenja pretpostavljenog.

Ključne riječi: međunarodno humanitarno pravo, nemeđunarodni oružani sukob, implementacija, Ženevske konvencije, Dodatni protokoli

\section{Uvod}

Ove se godine obilježava sedamdeset godina od usvajanja četiri Ženevske konvencije, koje se, kao cjelina, smatraju esencijom i jednim od najznačajnijih izvora međunarodnog humanitarnog prava. ${ }^{1}$ Povod usvajanju ovih konvencija bila je prosta činjenica da je Drugi svjetski rat ostavio za sobom brojne ljudske žrtve, a da na međunarodnom nivou nisu postojali propisi koji bi štitili ljudski život u onoj mjeri u kojoj je to u oružanom sukobu uopšte moguće. Naravno, sasvim je izvjesno da postojanje propisa na međunarodnom nivou nije dovoljno

1 Detaljnije: Lj. Mijović, „Povodom 50-godišnjice usvajanja Ženevskih konvencija“, u: Godišnjak Pravnog fakulteta, br. 23/99, Banjaluka, str. 247-254. 
da se spriječe zvjerstva i nečovječno postupanje prema ranjenim, bolesnim i civilnim žrtvama rata, čega smo, nažalost, bili bolno svjesni tokom minulog rata na prostorima bivše Jugoslavije, no ono ipak daje određenu pravnu osnovu da se, pored preventivne, ostvari i ona represivna ${ }^{2}$ uloga - da se počinioci takvih djela, koja se, uostalom, bez postojanja pravnih propisa i ne mogu okarakterisati kao protivpravna, kazne. Da bi se spriječila protivpravna postupanja u oružanom sukobu, bio on međunarodni ili unutrašnji ${ }^{3}$, neophodno je postojanje, pored međunarodne, i norme unutrašnjeg prava koja takvo postupanje zabranjuje, odnosno sankcioniše, u jednom, ili stvara pravni osnov za direktnu primjenu međunarodne norme, u drugom slučaju. Kako se za međunarodno humanitarno pravo osnovano može tvrditi da je obimno kodifikovana oblast međunarodnog prava, veoma bitnim pitanjem smatra se način provođenja njegovih odredaba $i$ na nacionalnom, odnosno nivou zakonodavstava i jurisdikcija zemalja potpisnica predmetnih kodifikacija. U vezi s tim se pitanje implementacije normi međunarodnog humanitarnog prava smatra izuzetno značajnim.

Novonastale države na području bivše Jugoslavije su, nakon raspada, izgradile sopstvene pravne poretke, koji, bez obzira na različitosti, i dalje pripadaju istom pravnom sistemu ${ }^{4}$, odnosno imaju sličnu pravnu tradiciju i nasljeđe. Stoga je u bavljenju pitanjem implementacije normi međunarodnog humanitarnog prava neophodno krenuti od sistema koji je postojao prije oružanih sukoba i raspada bivše Jugoslavije.

\section{Implementacija međunarodnog humanitarnog prava na području BiH (SFRJ) prije 1991. godine - pravni propisi i mehanizmi}

S obzirom na federativno uređenje kakvo je prije ratnih zbivanja postojalo u bivšoj Jugoslaviji, o implementaciji međunarodnog humanitarnog prava na području predratne Bosne i Hercegovine nemoguće je govoriti van konteksta odnosa koji je tad postojao, odnosno van pravnih i ustavnih okvira koji su tada bili na snazi. Ovakav stav je utoliko argumentovaniji ukoliko su nam poznati međunarodnopravni mehanizmi i propisi međunarodnog humanitarnog prava koji su tad bili na snazi (a većina njih se primjenjuje i danas) čiji je potpisnik bila SFRJ,

2 O preventivno-represivnoj funkciji detaljnije: A. Kaseze, Međunarodno krivično pravo, Beogradski centar za ljudska prava, Beograd, 2005.

3 Relevantna literatura koristi termin „nemeđunarodni oružani sukobi“ (eng. non-international armed conflict).

$4 \quad$ Misli se na podjelu na dva velika pravna sistema - angloamerički i evropski kontinentalni. 
a koje su kao federativne jedinice bile obavezne poštivati i tadašnje republike iste države.

Tako je SFRJ bila potpisnicom niza međunarodnopravnih dokumenata iz oblasti humanitarnog prava od kojih ćemo kao najopštije izdvojiti nekoliko. Tu su, ponajprije, Ženevske konvencije iz 1949. godine ${ }^{5}$, (uključujući Dodatne protokole), Konvencija o sprečavanju i kažnjavanju zločina genocida iz 1948. godine, Konvencija o zaštiti kulturnih dobara iz 1954. godine i dr. Međunarodnopravni standardi postavljeni (prije svega) ovim dokumentima (koji, naravno, nisu jedini, ali su najopštiji i s našeg gledišta najbitniji za aspekte kojima se ovaj rad bavi) predstavljali su pravni osnov za unutrašnji koncept zaštite ljudskih života i materijalnih dobara u vrijeme oružanog sukoba. Kao federativno uređena država, Jugoslavija je imala federalni ustav, s kojim su imali biti usklađeni ustavi svih federativnih jedinica, samim tim i predratne $\mathrm{BiH}$. Svaki od ovih ustava sadržavao je određen dio odredaba koje su predstavljale implementaciju međunarodnog humanitarnog prava, bilo da govorimo o formalnim izvorima tog prava (međunarodnim konvencijama), bilo da se radilo o običajnim pravilima međunarodnog ratnog ${ }^{6}$ prava. Pitanjem da li je i u kojoj mjeri postojao jaz između normativnog i stvarnog u oblasti implementacije međunarodnog humanitarnog prava $\mathrm{u}$ pravni sistem SFRJ, samim tim i BiH, pitanje je kojim se malo ko ozbiljnije bavio, jer je u to vrijeme mogućnost izbijanja unutrašnjeg oružanog sukoba izgledala apsurdno.

\section{Stanje u periodu od 1991. - 1995. godine}

Posljednji izbori koji su održani pred izbijanje ratnih sukoba doveli su na vlast lidere koji nisu bili u stanju da postignu mirni dogovor o disoluciji zajedničke države, a javnost je svakodnevno bila zasipana pozivima na oružje i konačni obračun sa predratnom državom. O tome kako su se i u kojoj mjeri poštovale norme međunarodnog humanitarnog prava u ovom periodu moguće je govoriti s nekoliko različitih aspekata. Zanemarujući političko, ne kao manje bitno, nego kao i danas teoretski i praktično sporno, s pravnog gledišta moguće je konstato-

Konvencija za poboljšanje položaja ranjenika i bolesnika u oružanim snagama u ratu; Konvencija za poboljšanje položaja ranjenika, bolesnika i brodolomnika oružanih pomorskih snaga; Konvencija o postupanju sa ratnim zarobljenicima i Konvencija o zaštiti građanskih lica za vrijeme rata.

$6 \quad$ Izraz „ratno pravo“ je vremenom evoluirao u izraz „humanitarno pravo“, s obzirom na činjenicu da je „rat“ označen kao protivpravno djelo, stoga je paradoksalno određenu vrstu pravnih propisa nazivati „ratnim pravom“. 
vati postojanje rasula pravnog sistema u ovom periodu. Politička previranja, a kasnije i oružani sukob, doveli su ne samo do raspada bivše Jugoslavije, već i do podjele Bosne i Hercegovine, te i pojave određenih državnopravnih institucija na svim ratujućim stranama. Koliko i kako su te institucije pravno zaista i funkcionisale, dovoljno govori podatak da se gotovo cijelim područjem $\mathrm{BiH}$ ratovalo, a da, skoro do pred kraj oružanog sukoba, nigdje nije došlo do proglašenja ratnog stanja. Proglašavanje ratnog stanja nije slučajno pomenuto, s obzirom na to da se ono smatra bitnim, jer podrazumijeva prelazak na pravni režim primjeren ratu, što, prosto rečeno, znači stupanje na snagu onih propisa kojima se štite ljudska prava i materijalna dobra u oružanom sukobu, a koji se propisi ponajprije odnose na zaštitu civila. To istovremeno znači derogiranje mirnodopskih propisa, ili pak, njihov ostanak na snazi, ukoliko se radi o propisima usklađenim sa međunarodnopravnim dokumentima koji regulišu oblast oružanih sukoba. Tako se zapravo i desilo da se na prostoru $\mathrm{BiH}$ ratovalo, a da, formalnopravno, ratnog stanja nije bilo. To, naravno ne znači da strane u sukobu nisu bile obavezne primjenjivati propise međunarodnog ratnog, odnosno humanitarnog prava, pri čemu i prije svega, imamo na umu Ženevske konvencije i Dodatne protokole. Politički lideri su, svjesni ove činjenice, učinili određene formalnopravne korake u pravcu otklanjanja ovog nesklada, te su, primjera radi, u Ženevi, 22. maja 1992. godine, na poziv Međunarodnog komiteta Crvenog krsta/križa (u daljem tekstu MKCK), zaključili Sporazum između predstavnika Alije Izetbegovića, Radovana Karadžića, te Miljenka Brkića, kojim se oni (preko svojih predstavnika) obavezuju da će poštovati pravila međunarodnog humanitarnog prava (pri čemu se posebno izdvaja problematika brige o ranjenima, bolesnim i mrtvima). ${ }^{7}$ Koliko je isti Sporazum bio politička farsa govori činjenica, da je i pored međunarodnopravne obaveze, preuzete na taj način, stvarno stanje stvari ukazivalo na potpuno nepoštovanje dogovorenog. Naime, Sporazum koji je prethodno pomenut, predviđa i obaveznu primjenu Protokola I, koji zahtijeva obavezno osnivanje Službe traženja pri Crvenom krstu, čiji je zadatak bio da prikuplja, evidentira, obrađuje i daje podatke o svim žrtvama rata - sopstvenim, savezničkim i neprijateljskim, te obavezu svih organa i organizacija, vojnih jedinica i ustanova da, u skladu sa zakonom, Službi traženja daju podatke koje ona od njih zatraži. Istine radi, službe traženja jesu bile obrazovane, mada, sudeći prema podacima $\mathrm{MKCK}^{8}$, nisu obavile svoj dio posla, iako glavnog krivca ne treba tražiti u službama traženja. Naime, prema odredbama međunarodnog humanitarnog prava, starješine strana u sukobu bile

Vidi Sporazum, dostupan na: https://casebook.icrc.org/case-study/former-yugoslaviaspecial-agreements-between-parties-conflicts (26. 2. 2019.)

$8 \quad$ Vidi Evidenciju MKCK o nestalim osobama na području BiH (januar, 1997.godine) i vidi Izjavu Službe traženja MKCK od 16.9.1997.god. 
su te čija je bila obaveza prikupljanja i distribucije podataka o ranjenim, bolesnim i umrlim pripadnicima neprijateljskih oružanih snaga. Istoj obavezi moralo je biti udovoljeno posredstvom starješina sanitetskih ustanova i jedinica koje su organizovale prikupljanje ranjenika, bolesnika i umrlih. Međunarodnopravno je bila postavljena obaveza i na formiranje Biroa za obavještavanje o ratnim zarobljenicima, čiji je osnovni zadatak morao biti usmjeren na prikupljanje i dostavu zainteresovanim silama i centralnoj agenciji podataka o ratnim zarobljenicima. Dokazano postojanje masovnih grobnica neidentifikovanih žrtvava širom $\mathrm{BiH}$ ukazuje na činjenicu da ova pravila nisu bila poštovana ni u minimalnom opsegu. Tako je došlo do tog da je samo u BiH život izgubilo više od 100.000 ljudi, a taj broj obuhvata i oko 31.500 nestalih osoba. ${ }^{9} \mathrm{~S}$ druge strane, neophodno je naglasiti da se od međunarodnih faktora, osim MKCK, $\mathrm{u}$ ovom periodu u ovu aktivnost nije uključio niko, bar ne u znatnijoj mjeri, a radilo se o problemu koji ni danas, dvadeset i četiri godine nakon obustave neprijateljstava, nije u potpunosti riješen, jer se prema nekim evidencijama na teritoriji $\mathrm{BiH}$ preko 7.000 lica još uvijek vode kao nestala. ${ }^{10}$ Svakodnevna praksa iz tog perioda potvrđivala je nepoštovanje obaveza preuzetih Sporazumom iz maja 1992. godine, jer je do podataka o nestalim licima bilo izuzetno teško doći, s obzirom na postojanje velikog broja "privatnih logora” odnosno logora koje su držali pojedinci, mimo vojne komande, a u kojima su se nalazili kako pripadnici oružanih snaga, tako i civili. Institucionalni putevi traganja za takvim osobama nisu se pokazali kao efikasni, a oni slučajevi kad je do pronalaženja pojedinih zatočenih osoba i došlo, obično su bili plod angažovanja članova porodice, politički i vojno uticajnih pojedinaca i sl., što se nije bitno promijenilo ni nakon obustave sukoba, iako su se i potpisivanjem Dejtonskog mirovnog sporazuma strane u sukobu obavezale na oslobađanje i repatrijaciju svih ratnih zarobljenika, bez ikakvog odlaganja. Što se tiče aktivnosti vezanih za nestale osobe, kao što je i ranije rečeno, jedina Služba traženja koja je svo vrijeme rata vršila aktivnosti na traganju za nestalim osobama bila je zapravo Služba traženja MKCK, tako da je ova Služba, zahvaljujući mogućnosti angažovanja na velikom, ako ne i kompletnom području $\mathrm{BiH}$, pa i bivše Jugoslavije, bila zapravo jedina koja je imala mjerodavne podatke o nestalim osobama.

Značajno nepoštovanje normi međunarodnog humanitarnog prava postojalo je i u odnosu na postupanje prema ratnim zarobljenicima i civilima u toku oružanog sukoba u BiH. ${ }^{11}$ Pravljenje distinkcije predviđene međunarodnim humanitarnim

9 Detaljnije: Bosna i Hercegovina - Osobe nestale usljed oružanih sukoba tokom 1990-ih: pregled stanja, Međunarodna komisija za nestale osobe (ICMP), Sarajevo, 2014.

10 Prema Evidenciji Instituta za nestale osobe Bosne i Hercegovine, dostupno na: http:// www.ino.ba/default.aspx?langTag=hr-HR\&template_id=210\&pageIndex $=1$ (26. 2. 2019.)

11 O kršenju ljudskih prava u Bosni i Hercegovini u vrijeme trajanja oružanog sukoba detalj- 
pravom koja se odnosi na građanska lica kao neprijateljske državljane, državljane neutralnih država, lica bez državljanstva i izbjeglice, nije bilo od velikog značaja u sukobu u Bosni i Hercegovini, s obzirom na njegovu specifičnost i karakteristike nemeđunarodnog, etničkog, čak i vjerskog.

Oslobađanje i repatrijacija, kao dva veoma bitna pitanja humanitarnog prava, tek su Dejtonskim mirovnim ugovorom ${ }^{12}$ bila detaljnije uređena i to na način koji predviđa bezuslovno i neodložno oslobađanje i repatrijaciju svih boraca i civila koje ratujuće strane drže u vezi sa sukobom. Kao dalje obaveze ugovornih strana predviđeno je da plan oslobađanja i repatrijacije, u koordinaciji sa aktivnostima MKCK, strane imaju provesti u roku od 30 dana po prenosu ovlaštenja. Dalje odredbe ovog člana Opšteg okvirnog sporazuma predvidjele su obavezu strana da, takođe u saradnji sa MKCK, sačine sveobuhvatne spiskove zarobljenika, te da ih predaju drugim stranama ugovornicama, Zajedničkoj vojnoj komisiji i Visokom predstavniku. U stavu (e) istog člana Dejtonskog sporazuma kaže se da su strane obavezne obezbijediti MKCK-u neometan pristup do svih mjesta gdje se drže zarobljenici, te se predviđa obaveza ovlaštenih lica u takvim mjestima da predstavnicima MKCK omoguće razgovor nasamo najmanje 48 sati prije puštanja te osobe. ${ }^{13}$ Bolna je istina, $s$ druge strane, da se za vrijeme trajanja sukoba, a čak i danas, dvadeset tri godine nakon Mirovnog sporazuma, trgovalo i trguje informacijama o nestalim ratnim zarobljenicima.

Problem izbjeglih i raseljenih lica smatra se jednim od najtežih tokom trajanja oružanog sukoba u BiH. Naime, s obzirom na to da je jedno od osnovnih obilježja ovog sukoba bila činjenica da se sukob vodio između etnički i vjerski različitih grupacija, nezvanična politika etničkog čišćenja dovela je do brojke od pola miliona izbjeglih i million raseljenih $\operatorname{lica}^{14}$. O tretmanu raseljenih i izbjeglih lica uglavnom su se brinuli opštinski krizni štabovi i međunarodne humanitarne organizacije (MKCK, UNHCR i razne vjerske humanitarne organizacije). Ista pomoć je, nažalost, s obzirom na ogroman broj i stalan priliv izbjeglih i raseljenih lica, bila nedovoljna. S obzirom na dimenzije ovog problema, zaključak koji se može izvesti kad je riječ o statusu izbjeglih i raseljenih lica jeste da niti jedna

nije vidi: Ž. Papić i dr., Međunarodne politike podrške zemljama Jugoistočne Evrope-Lekcije (ne)naučene u BiH, Poglavlje XIII, Ljiljana Mijović, Ljudska prava u BiH, Sarajevo, 2002. god.

12 Okvirni mirovni sporazum, čl. 9.

13 Vidi čl. 9. Okvirnog sporazuma.

Podaci Ministarstva za ljudska prava i izbjeglice $\mathrm{BiH}$ iz „Komparativne analize prava izbjeglih i raseljenih lica“ (2005.), dostupno na: http://www.mhrr.gov.ba/PDF/UporednaAnalizaEngleski.pdf (27. 02. 2009.) 
oblast međunarodnog humanitarnog prava nije kršena u većoj mjeri od ove. Problem ove populacije nije u potpunosti mogao riješiti ni Mirovni sporazum, jer je njegov prioritetni cilj bio prestanak sukoba. Smatralo se da će oktroisanom implementacijom 16 osnovnih međunarodnopravnih dokumenata iz oblasti zaštite osnovnih ljudskih prava i sloboda biti trasiran put ne samo povratku raseljenih i izbjeglih, nego i uspostavljanju sistema zaštite ljudskih prava i sloboda u cjelosti.

Nezaobilazno pitanje, kada govorimo o oblasti zaštite osnovnih ljudskih prava i sloboda, kako u miru, tako i u vrijeme trajanja oružnih sukoba, jeste pitanje odgovornosti za kršenje osnovnih ljudskih prava i sloboda. To pitanje u vrijeme trajanja oružanih sukoba prerasta u pitanje krivične odgovornosti za kršenje normi međunarodnog humanitarnog prava. Koncept individualne krivične odgovornosti, odnosno odgovornosti pojedinaca koji krše norme međunarodnog humanitarnog prava rezultirao je, još u vrijeme trajanja sukoba na području bivše Jugoslavije, uključujući i sukob na području $\mathrm{BiH}$, nastankom Tribunala u Hagu, čiji je zadatak bio da kazni počinioce zločina proizašlih iz sukoba na području bivše Jugoslavije. U početku isključiva nadležnost Tribunala u Hagu, a na osnovu principa univerzalne jurisdikcije za ovu vrstu međunarodnih krivičnih djela, prešla je, nakon osnivanja Suda $\mathrm{BiH}$ na taj, a dijelom i na entitetske sudove.

\section{Državnopravna struktura BiH nastale Dejtonskim mirovnim sporazumom ${ }^{15} \mathrm{i}$ izmjene $u$ oblasti implementacije međunarodnog humanitarnog prava}

Nakon raspada bivše Jugoslavije i okončanja oružanih sukoba, Dejtonskim mirovnim sporazumom (re)konstituisana je novembra 1995. godine Bosna i Hercegovina, sačinjena od dva entiteta, te je predviđeno da će, prema odredbama Sporazuma, "nastaviti svoje pravno postojanje po međunarodnom pravu kao država sa unutrašnjom strukturom, modificiranom, kako je ovdje određeno i sa postojećim međunarodno priznatim granicama." ${ }^{16}$ Kako je Sporazum prvenstveno bio usmjeren na postizanje prekida neprijateljstava, trajnu uspostavu mira i obnovu devastiranog područja, u samom Sporazumu je propušteno decidno određenje oblika državnog uređenja, odnosno data je, u prethodno citiranoj odredbi neprecizna formulacija o obliku državnog uređenja (“...sa unutrašnjom strukturom, modificiranom, kako je ovdje određeno...”). Razlog osvrtanju na ovu

15 Detaljnije o međunarodnopravnom subjektivitetu BiH vidjeti: Mijović, Ljiljana, Osnove međunarodnog javnog prava, Banjaluka, 2019. god. str. 98.;

16 Aneks 4 Dejtonskog sporazuma, čl.1, st.1. 
odredbu počiva u činjenici da, ukoliko državno uređenje nije precizno određeno, ostaje nejasno i pitanje standardizovane implementacije međunarodnopravnih normi bilo koje vrste, pa tako i normi međunarodnog humanitarnog prava. Danas je više nego očita činjenica da na području Bosne i Hercegovine ne postoji jedinstven pravni sistem i da u toj nejedinstvenosti nema ni pravne sigurnosti. Odredbama sadržanim u Aneksu IV, čl. 2 Bosna i Hercegovina, kao i oba njena entiteta, obavezuju se, istina, na primjenu „najvišeg nivoa međunarodno priznatih osnovnih ljudskih prava i sloboda” (podrazumijevajući pod tim ljudska prava kako u doba mira, tako i u vrijeme oružanih sukoba) ali su, bez obzira na obaveznost primjene međunarodnopravnih standarda na nivou Bosne i Hercegovine, oni koji sankcionišu nepoštivanje istih standarda ipak entitetski (pa i kantonalni) pravosudni organi, uz ograničenu nadležnost Suda $\mathrm{BiH}$, te apelacionu nadležnost Ustavnog suda $\mathrm{BiH}$ u segmentu zaštite ljudskih prava i sloboda. U tom kontekstu potrebno je pomenuti da, i pored proklamovanja obaveze poštovanja međunarodnih standarda i obaveze sadržane u Aneksu VII u odnosu na izbjegla i raseljena lica ${ }^{17}$ i pitanje repatrijacije ${ }^{18}$, broj izbjeglih lica koja su se vratila u $\mathrm{BiH}$ ne prelazi 40 odsto, a raseljenih u 2018. godini u $\mathrm{BiH}$ ima još 98.574 , prema podacima UNHCR-a. ${ }^{19}$ Jednim od razloga za mali broj povratnika u predratno mjesto stanovanja, pored teškoća vezanih za nepostojanje infrastrukture ili njenog nedovoljnog nivoa, smatra se još jedno nepoštovanje obaveze preuzete Mirovnim sporazumom, koje se odnosi na prevenciju i suzbijanje poticaja na širenje mržnje i neprijateljstava, akata odmazde, zaštitu manjinskog stanovništva, zabranu progona itd., što je predviđeno kao niz mjera u Aneksu VII. Sve to rezultiralo je time da, više od dvije decenije nakon Mirovnog sporazuma, i dalje postoje centri za kolektivni smještaj, povratnici koji nisu ušli u posjed svoje imovine i oni kojima je to pošlo za rukom ali, iako se nalaze u svojim kućama i stanovima, nemaju redovan izvor prihoda, da i ne spominjemo zdravstvenu zaštitu i socijalno osiguranje.

17 U čl.1. ovog Aneksa sadržana je odredba o pravu svih izbjeglih i raseljenih lica da se slobodno vrate u svoje domove, da im se omogući povrat imovine i pravo na kompenzaciju za svu imovinu koja im se ne može vratiti.

18 Stavom 2. istog člana, strane ugovornice su se obavezale da će osigurati svim ovim licima bezbjedan povratak, bez uznemiravanja, zastrašivanja, progona ili diskriminacije, te da će (stav 3.) preduzeti sve neophodne korake kako bi se spriječile aktivnosti usmjerene na ometanje i sprečavanje bezbjednog povratka.

19 Dostupno na: https://www.unhcr.org/see/wp-content/uploads/sites/57/2018/05/BiH-Country-Fact-Sheet-January-2018-002.pdf(26. 2. 2019.) 


\section{Odnos međunarodnog i unutrašnjeg prava Bosne i Hercegovine}

Kako se, u slučaju BiH radi o složenoj državnopravnoj strukturi, u odgovoru na pitanje u kakvom odnosu stoji unutrašnje pravo BiH prema međunarodnom, potrebno je krenuti od osnovnih elemenata strukture $\mathrm{BiH}$, čiji je Ustav, kao što je poznato, dio Dejtonskog mirovnog ugovora. Tako u preambuli Ustava (Aneks IV Dejtonskog sporazuma) stoji da su Bošnjaci, Srbi i Hrvati, kao konstitutivni narodi $\mathrm{BiH}$ „opredjeljeni za suverenitet, teritorijalni integritet i političku nezavisnost Bosne i Hercegovine”, dok u članu 10. stoji da „SRJ i BiH priznaju jedna drugu kao suverene, nezavisne države, unutar njihovih međunarodnih granica", na osnovu kojih odredaba je vidno da se nosiocem međunarodnopravnog subjektiviteta smatra $\mathrm{BiH}$. Iako je u poslijeratnom periodu došlo do prenosa nadležnosti sa entiteta na nivo $\mathrm{BiH}$ u pojedinim segmentima, u čl. 3. Aneksa IV (Ustava), nadležnostima $\mathrm{BiH}$ smatraju se vanjska, spoljnotrgovinska, carinska i monetarna politika, finansiranje institucija i plaćanje međunarodnih obaveza $\mathrm{BiH}$, pitanja imigracije, izbjeglica i azila, provođenje međunarodne i međuentitetskih politika, regulisanje krivičnih propisa, uspostava i funkcionisanje zajedničkih i međunarodnih komunikacija, regulisanje međuentitetskog transporta, te kontrola vazdušnog prometa, dok su nadležnosti entiteta od značaja za međunarodnopravni aspekt regulisane istim članom, st.2, u kojem se kaže da entiteti imaju pravo da uspostave posebne paralelne odnose sa susjednim zemljama u skladu sa suverenitetom i teritorijalnim integritetom Bosne i Hercegovine. Analizom navedenih odredaba uočavamo da, ukoliko atribute suverenosti ${ }^{20}$ shvatimo u njihovom doktrinarnom konceptu, međunarodnopravni subjektivitet u punom obimu (dakle, u tretmanu samostalnog subjekta međunarodnog prava) počiva prvenstveno na $\mathrm{BiH}$, mada se u navedenom članu (stav 2.) predviđa mogućnost entiteta na "uspostavljanja posebnih paralelnih odnosa sa susjednim zemljama". Iako ograničeno rationae personae („susjedne zemlje”, ograničavanje broja subjekata, eventualnih ugovornih strana) i rationae materiae („posebni paralelni odnosi”, bez preciziranja vrste i obima tih odnosa), ipak se uočava i ispoljavanje jednog dijela ugovornog kapaciteta i na strani entiteta, što daje osnova tvrdnji da je međunarodnopravni subjektivitet $\mathrm{BiH}$ u segmentu prava na ugovaranje, veoma specifičan, ili pravnički rečeno, sui generis. U prilog toj tvrdnji ide i činjenica da u daljem tekstu Sporazuma (stav 2. (d) pomenutog člana) stoji da svaki entitet može sklopiti sporazume sa državama i međunarodnim organizacijama, uz pristanak Parlamenta $\mathrm{BiH}$, te da se zakonom može precizirati da određena vrsta tih sporazuma ne traži pristanak Parlamenta. Ovakvo rješenje čini se neobičnim,

20 Misli se na ius legationis - pravo predstavljanja i ius tractatum - pravo na zaključenje ugovora, ne i na ius belli (ius ad bellum). 
jer je najčešće prisutno kod federativno uređenih država, što BiH svakako nije. Praktični značaj ove odredbe neposredno je ograničen djelatnošću Parlamentarne skupštine $\mathrm{BiH}$, iako ova odredba ne precizira da li se pristanak Parlamenta ima smatrati za prethodno dato ovlaštenje na zaključenje ugovora ili je riječ o naknadnoj saglasnosti na već zaključeni ugovor. Ispravnije bi bilo ovu odredbu tumačiti kao mogućnost davanja prethodnog ovlaštenja za zaključenje ugovora, nego kao naknadnu potvrdu, koju bi bilo teško razlučiti od postupka ratifikacije ugovora. Sama ratifikacija međunarodnih ugovora predviđena je članom 4., st.4 (d) i odvija se u sadejstvu Predsjedništva i Parlamentarne skupštine. Na osnovu izloženog, a povodom određivanja ugovornog kapaciteta, kao vida ispoljavanja međunarodnopravnog subjektiviteta, moglo bi se ponovo ustvrditi da se radi o specifičnostima koje ne dozvoljavaju jasno razgraničenje nadležnosti, odnosno precizno određenje obima i načina ispoljavanja međunarodnopravnog subjektiviteta u slučaju $\mathrm{BiH}$, kao i da je velika vjerovatnoća da su iste formulacije s namjerom postavljene okvirno, kako bi se praksom i razvojem situacije definitivno uobličio isti subjektivitet. Time je, na drugoj strani, ostavljena mogućnost slobodne interpretacije, u zavisnosti od, prije svega političkih interesa, ne samo pravne prirode ugovornog kapaciteta $\mathrm{BiH}$ i njenih entiteta, već i samog oblika državnog uređenja. Pored pomenutog, vrijedno je obratiti pažnju i na pravo predstavljanja (ius legationis) kao vid ispoljavanja suvereniteta, koje prema tekstu Sporazuma, u potpunosti počiva na $\mathrm{BiH}$, tj. njenim organima ${ }^{21}$, iako postoje i predstavništva entiteta $\mathrm{u}$ inostranstvu ${ }^{22}$. S druge strane, kada je upravo riječ o vođenju vanjske politike (a koja je segment atributa ius legationis), ne može se reći da, bar posredno, entiteti nemaju nikakvih ovlaštenja, jer član Predsjedništva (biran od strane entiteta), učestvujući u sprovođenju spoljne politike $\mathrm{BiH}$, provodi u djelo, prvenstveno interese entiteta u kome je biran, te iako je predviđeno da se „nastoji da Predsjedništvo usvoji sve odluke putem konsenzusa” (čl.5, st. 2(c) Ustava), član Predsjedništva može odluku proglasiti „destruktivnom po vitalni interes entiteta iz kojeg je biran” (čl.5, st.2 (d) Ustava), u kojem slučaju se odluka upućuje parlamentu entiteta iz kojeg je član Predsjedništva koji je glasao "protiv”. Odluka neće stupiti na snagu ukoliko parlament entiteta dvotrećinskom većinom u roku od deset dana odluku Predsjedništva oglasi „destruktivnom po vitalni interes entiteta", čime se, mada indirektno, ipak daje mogućnost entitetima da učestvuju u vođenju spoljne politike. U ovako neprecizno i široko postavljenim okvirima međunarodnopravnog subjektiviteta vidna je osjetljivost s kojom su

21 Vidi odredbe Dejtonskog sporazuma o nadležnosti institucija BiH.

22 Republika Srpska ima predstavništava u Belgiji, Njemačkoj, Izraelu, Ruskoj federaciji, SAD, Grčkoj, Austriji i Srbiji, dostupno na: http://www.vladars.net/sr-SP-Cyrl/Vlada/ Predstavnistva/Pages/default.aspx (28. 2. 2019.) 
postupali tvorci Dejtonskog sporazuma prilikom iznalaženja svim stranama u sukobu prihvatljivih rješenja, kao i potreba da se političkim dogovorom unutar $\mathrm{BiH}$ postignu preciznije formulisane nadležnosti vezane za ispoljavanje međunarodnopravnog subjektiviteta.

\section{Nacionalne mjere implementacije međunarodnog humanitarnog prava}

Svrha prethodnog poglavlja bila je da ukaže na složenost pravne strukture $\mathrm{BiH}$ i njenih entiteta, te da, određujući pojam međunarodnopravnog subjektiviteta $\mathrm{BiH}$, ukaže na organe i nivoe na kojima je potrebno insistirati na mjerama implementacije međunarodnog humanitarnog prava od strane nacionalnog zakonodavstva. S obzirom na to da se radi o državi koja se smatra jednim od sukcesora predratne SFRJ, implementacija normi međunarodnog humanitarnog prava podrazumijevala je pristupanje $\mathrm{BiH}$ određenom broju ugovora međunarodnog humanitarnog prava, odnosno njihovu naknadnu ratifikaciju, zavisno od tog koji je način pristupanja samim ugovorom predviđen. Ratifikacija međunarodnih ugovora je, kao što je ranije rečeno, jedan od vidova ispoljavanja međunarodnopravnog subjektiviteta $\mathrm{BiH}$, i zavisno od tipa ugovora, odnosno oblasti koju reguliše, vrši se, prema Ustavu $\mathrm{BiH}$ na različite, u prethodnom poglavlju opisane načine.

\section{1. Članstvo $\mathrm{BiH}$ u ugovorima međunarodnog humanitarnog prava}

Bez obzira na oružani sukob koji je postojao u to vrijeme, $\mathrm{BiH}$ je primljena u članstvo Ujedinjenih nacija 6. aprila 1992. godine, čime je izvršeno kolektivno priznanje države čija se struktura, samim tim i subjektivitet, bitno razlikovao od današnje strukture i subjektiviteta. Prijem u OUN je podrazumijevao i obavezu pristupanja velikom broju ugovora međunarodnog javnog, samim tim i humanitarnog prava. Pre-dejtonska $\mathrm{BiH}$ je u skladu s tim izvršila pristupanje, odnosno ratifikaciju određenog broja multilateralnih ugovora međunarodnog humanitarnog prava, koja se validnost pristupanja nije pojavila kao upitna (re)konstituisanjem dejtonske $\mathrm{BiH}$.

Tako je, primjera radi, pre-dejtonska $\mathrm{BiH}$ pristupila:

- Ženevskim konvencijama iz 1949. godine 31. decembra 1992. godine;

- Konvenciji o sprečavanju i kažnjavanju zločina genocida iz 1948. godine 29. decembra 1992. godine; 
- Konvenciji o zaštiti kulturnih dobara u slučaju oružanog sukoba iz 1954. godine, 12. jula 1993. godine;

- Konvenciji o zabrani razvoja, proizvodnje i upotrebe bakteriološkog (biološkog) oružja i otrova i o njihovom uništenju iz 1972. godine, 15. avgusta 1994. godine;

- Dodatnom Protokolu na Ženevske konvencije iz 1949. godine od 1977. godine (Protokol I), 31. decembra 1992. godine;

- Dodatnom Protokolu na Ženevske konvencije iz 1949. godine od 1977. godine (Protokol II), 31. decembra 1992. godine;

- Konvenciji o zabrani ili restriktivnoj upotrebi određenog konvencionalnog naoružanja iz 1980. godine, 1. septembra 1993. godine (uključujući Protokole I, II i III);

- Protokolu o zabrani ili restriktivnoj upotrebi mina iz 1980. godine, 1. septembra 1993. godine (uključujući Protokole I, II i III);

- Protokolu o zabrani upotrebe zapaljivog oružja (Protokol III) iz 1980. godine, 1. septembra 1993.godine, (uključujući Protokole I, II i III).

Pri pominjanju prethodno iznešenih podataka (a pobrojani su samo oni ugovori koji se smatraju najrelevantnijim u odnosu na pravo oružanih sukoba), potrebno je naglasiti da je predratna SFRJ (čijim se pravnim sukcesorima smatraju novonastale države) bila potpisnica svih tih ugovora, počevši od Ženevskih konvencija, koje je potpisala 10. februara 1959. godine, a ratifikovala 21. aprila 1959. godine, pa nadalje.

Nakon prestanka oružanog sukoba, $\mathrm{BiH}$ je pristupila i ostalim relevantnim multilateralnim ugovorima međunarodnog humanitarnog prava i to:

- Konvenciji o zabrani upotrebe hemijskog oružja iz 1993. godine, 25. februara 1997. godine;

- Statutu Međunarodnog krivičnog suda (ICC) iz 1998. godine, 11. aprila 2002. godine;

- Dodatnom Protokolu na Ženevske konvencije iz 1949. godine(Protokol III) iz 2005. godine, 14. marta 2006. godine, te

- Konvenciji o zaštiti svih osoba od prisilnog nestanka iz 2006. godine, 30. marta 2012. godine.

$\mathrm{Na}$ ovaj način, pristupanjem $\mathrm{BiH}$ svim pobrojanim ugovorima, stvorena je pravna obaveza države na poštovanje propisa, te formalnopravna osnova za primjenu normi međunarodnog humanitarnog prava. To se, međutim i nažalost, ne samo $\mathrm{u} \mathrm{BiH}$, nego ni u bilo kojoj od zemalja ugovornica, ne može smatrati i istovremenim činom implementacije normi sadržanih u tim ugovorima. $U$ vezi s tim, 
potrebno je podsjetiti na različitost teorija o odnosu unutrašnjeg i međunarodnog prava ${ }^{23}$, odnosno na danas opšteprihvaćen stav po kojem obaveze države po međunarodnom pravu imaju prvenstvo u odnosu na unutrašnji pravni poredak, te da se, u slučaju nesklada između unutrašnjeg i međunarodnog prava, države ne mogu pozivanjem na unutrašnje propise osloboditi međunarodnih obaveza. U skladu sa ovim shvatanjem, postojanje domaćeg propisa kojim se određuje način provođenja međunarodnih normi nije neophodan uslov za izvršenje obaveza proizašlih na osnovu međunarodnog prava, jer se obaveze preuzete na međunarodnom nivou smatraju pravno važećim već činom pristupanja ugovoru, $s$ međunarodnopravnog aspekta. Unutrašnje metode implementacije se razlikuju od države do države, opet u zavisnosti od njenih unutrašnjih propisa, ali se u suštini svode na inkorporaciju (in toto) ili usklađivanje sa normama međunarodnog ugovora izmjenom domaćih propisa (u za to predviđenoj zakonodavnoj proceduri), a u cilju postizanja cjelovitosti unutrašnjeg i međunarodnog prava, odnosno sklada između unutrašnjeg prava države i njenih obaveza prema međunarodnom pravu. U vezi s tim, države svojim najvišim pravnim aktima propisuju organe nadležne za zaključenje međunarodnih ugovora, postupak provođenja međunarodnih ugovora, kao i zakonske postupke predviđene za stvaranje pravne osnove primjene i poštovanja međunarodnog prava, koji pojmovi su, kad je riječ o $\mathrm{BiH}$, pojašnjeni u odjeljku koji se tiče njene državnopravne strukture.

\section{Primjena Ženevskih konvencija i pripadajućih protokola}

Bez namjere da zalazimo $\mathrm{u}$ analizu prirode oružanog sukoba koji se vodio $\mathrm{u}$ Bosni i Hercegovini, potrebno je naglasiti da obaveza poštovanja pravila međunarodnog humanitarnog prava za vrijeme trajanja oružanog sukoba postoji za sve strane $u$ sukobu, bez obzira na to da li im je priznat međunarodnopravni subjektivitet, ili ne. Pravni osnov za ovakav vid ponašanja kao obavezan nalazimo u čl. 3. Ženevskih konvencija iz 1949. godine, prema kojem su svi pripadnici strana u sukobu, bili priznati kao ratujuća strana ili ne, obavezni da poštuju osnovna pravila međunarodnog humanitarnog prava. Pored navedenog, propis koji konstituiše tu obavezu, kao i primjenu normi koje se tiču zaštite, jest i Dopunski protokol II iz 1977. godine, u kojem stoji da se predviđena zaštita proteže i na sve oružane sukobe „koji se odvijaju na teritoriji visoke strane ugovornice između njenih oružanih snaga i otpadničkih oružanih snaga ili drugih organizovanih naoružanih grupa koje, pod odgovornom komandom, vrše takvu kontrolu nad dijelom njene teritorije koja im omogućuje da vode neprekidne i usmjerene voj- 
ne operacije i da primjenjuju ovaj Protokol." ${ }^{24} \mathrm{U}$ nastavku istog člana naglašava se da ista odredba ne važi u slučajevima unutrašnjih nemira i zategnutosti, pobune, izolovanih ili sporadičnih akata nasilja i njima sličnih akata, jer to ne ulazi u definiciju oružanih sukoba. Opisana zaštita regulisana je članom 4. istog Protokola i ima se, dakle, primijeniti prema svim učesnicima u sukobu, a odnosi se, prije svega, na zabranu nepoštivanje načela milosrđa (zabrana izdavanja komande po kojoj ne smije biti preživjelih), zabranu nasilja, mučenja, sakaćenja i sl., izršavanja kolektivne kazne, uzimanja talaca, vršenje akata terorizma, povrede ljudskog dostojanstva, ropstva i trgovine robljem, pljačku, te prijetnju da će biti izvršeno bilo koje od navedenih djela. ${ }^{25}$

Osnov za primjenu ovih pravila predstavlja tendencija brisanja razlike između međunarodnog oružanog sukoba i onoga što se u humanitarnom pravu više ne naziva „građanski rat”, već „nemeđunarodni oružani sukob” ${ }^{26}$. Govoreći, dakle o primjenjivosti pravila međunarodnog humanitarnog prava u međunarodnim i nemeđunarodnim oružanim sukobima, „prvo što nam pada u oči je ogromna razlika u broju primjenjivih pravila. Ženevske konvencije i njihovi Dodatni protokoli sadrže dvadesetak pravila koja se odnose na unutrašnje oružane sukobe, nasuprot skoro pet stotina pravila koja se primjenjuju na međunarodne oružane sukobe. Pri tome se sa sigurnošću može tvrditi da su problemi, sa humanitarne tačke gledišta potpuno isti, bilo da su meci ispaljeni unutar ili preko državnih granica. Objašnjenje za ovu ogromnu razliku u broju pravila počiva u frazi „državni suverenitet"... Zbog toga je usvajanje člana 3., koji je zajednički svim Ženevskim konvencijama 1949.godine na Diplomatskoj konferenciji predstavljalo revolucionarno dostignuće - bio je to prvi prodor kroz zid državne suverenosti." ${ }^{27}$ Ovaj član, koji je zajednički svim Ženevskim konvencijama, ne samo da briše razliku između međunarodnih i „nemeđunarodnih”, (unutrašnjih sukoba), već omogućava i primjenu čitavog niza drugih pravila međunarodnog prava u unutrašnjim oružanim sukobima. Osnov za ovakvo shvatanje počiva u tome da je „rat uvijek rat...za svakoga ko je vidio posljedice." ${ }^{28}$ Kada govorimo o situacijama koje podrazumijevaju sukob u okvirima granica jedne države, potrebno je naglasiti da i tu postoje izvjesne razlike, s obzirom na odnos drugih država ili međunarodne zajednice u cjelini, prema tom sukobu, uslijed čega je moguće razlikovati internacionalizovani građanski rat i isključivi unutrašnji sukob.

\footnotetext{
$24 \quad$ Čl.1., Protokola II na Ženevske konvencije.

25 Vidi čl.4. Protokola II na Ženevske konvencije.

26 Eng. non-international armed conflict.

27 Gasser, Hans-Peter, International Humanitarian Law, Haupt, 1993. str. 21.

$28 \quad$ Ibid., str.66.
} 


\section{Primjena najvažnijih principa međunarodnog humanitarnog prava u pravnom sistemu BiH}

Pitanje ratifikacije, odnosno pristupanja međunarodnim ugovorima, kako je već naglašeno, segment je nadležnosti $\mathrm{BiH}$ i tek neznatnim dijelom i posredno, njenih entiteta. Kada je u pitanju pravni sistem entiteta, moguće je govoriti samo o propisima koji su, u manjoj ili većoj mjeri usklađeni sa normama međunarodnog humanitarnog prava, a čije je donošenje u okviru nadležnosti entiteta. (Ne) poštivanje normi međunarodnog humanitarnog prava, bez obzira na to da li se radi o običajnim ili normativnim pravilima $\mathrm{u}$ formalnom smislu, predstavlja najznačajniji segment implementacije međunarodnog humanitarnog prava. Kao takvo, ono je, u manjoj ili većoj mjeri, predmet sankcionisanja krivičnopravnog zakonodavstva, u smislu ustanovljavanja odgovornosti za učinjene povrede normi međunarodnog humanitarnog prava. Ovakav koncept je, prije sukoba u $\mathrm{BiH}$, bio zastupljen na nivou SFRJ, kao federativne države, ali su pojedini segmenti zaštite bili sadržani i u krivičnim zakonima federativnih jedinica, dakle i SR BiH. U toku i nakon oružanog sukoba na području $\mathrm{BiH}$, došlo je, kako je to već nekoliko puta naglašeno do (re)konstituisanja pravnog sistema, što je rezultiralo ranije opisanom pravnom strukturom. U tom kontekstu, krivičnopravna oblast je stavljena u nadležnost $\mathrm{BiH}$, mada entiteti imaju sopstvene krivične zakone, kao i zakone o krivičnom postupku. U odnosu na Sud $\mathrm{BiH}$, ne postoji opšta nadležnost u krivičnopravnoj oblasti, niti nadređenost Suda $\mathrm{BiH}$ redovnim sudovima entiteta $\mathrm{u}$ smislu apelacione nadležnosti), već je nadležnost ovog Suda u krivičnopravnoj oblasti Zakonom o Sudu $\mathrm{BiH}^{29}$ određena u odnosu na krivična djela predviđena Krivičnim zakonom $\mathrm{BiH}^{30}$, dok se, pored tih djela, Sud $\mathrm{BiH}$ smatra nadležnim $\mathrm{i}$ za djela predviđena zakonima entiteta i Brčko Distrikta, kada ta djela: a) ugrožavaju suverenitet, teritorijalni integritet, političku nezavisnost, nacionalnu sigurnost i međunarodni subjektivitet $\mathrm{BiH}$; b) mogu imati ozbiljne reperkusije ili štetne posljedice na privredu $\mathrm{BiH}$, ili mogu izazvati druge štetne posljedice za $\mathrm{BiH}$ ili mogu izazvati ozbiljnu ekonomsku štetu ili druge štetne posljedice izvan teritorije datog entiteta ili Brčko Distrikta.

Kada je u pitanju primjena normi međunarodnog humanitarnog prava, nadležnost postupanja Suda $\mathrm{BiH}$ u pomenutom Zakonu o Sudu BiH predviđena je za djela određena Glavom XVII Krivičnog zakona BiH kao krivična djela protiv čovječnosti i vrijednosti zaštićenih međunarodnim pravom (čl. 171. - 203.). Među pobrojanim djelima se, kao najznačajnija za primjenu međunarodnog hu-

29 Službeni glasnik BiH, br. 49/09, 74/09, 97/09. 
manitarnog prava, smatraju djela genocida (čl. 171.), zločina protiv čovječnosti (čl. 172.), ratnog zločina protiv civilnog stanovništva (čl. 173.), ratnog zločina protiv ranjenika i bolesnika (čl. 174.), ratnog zločina protiv ratnih zarobljenika (čl. 175.), organizovanja grupe ljudi i podstrekavanja na činjenje krivičnih djela genocida, zločina protiv čovječnosti i ratnih zločina (čl. 176.), protivpravnog ubijanja i ranjavanja neprijatelja (čl. 177.), protivpravnog oduzimanja stvari od ubijenih i ranjenih na ratištu (čl. 178.), povrede zakona ili običaja rata (čl. 179.), kao i pitanja individualne i komandne odgovornosti (čl. 180.), povrede parlamentara (čl. 181.), neopravdanog odgađanja povratka ratnih zarobljenika (čl. 182.), uništavanja kulturnih, istorijskih i religijskih spomenika (čl. 183.), zloupotrebe međunarodnih znakova (čl. 184.), prisilnog nestanka lica (čl. 190. a)), nedozvoljenog oružja i drugih borbenih sredstava (čl. 193. a)).

Pored navedenog, članom 7. Zakona o Sudu BiH predviđena je i nadležnost ovog Suda (st. 3(a)) da „zauzima konačan i pravno obvezujući stav u vezi s provođenjem zakona $\mathrm{BiH}$ i međunarodnih ugovora na zahtjev bilo kojeg suda entiteta ili bilo kojeg suda Brčko Distrikta kojem je povjereno provođenje zakona BiH", kao i nadležnost Suda (st. 3(b)) „Za donošenje praktičnih uputstava za primjenu krivičnog materijalnog prava $\mathrm{BiH}$ iz nadležnosti Suda u vezi s krivičnim djelima genocida, zločina protiv čovječnosti, ratnih zločina i kršenje zakona i običaja rata, te pojedinačnom krivičnom odgovornošću vezano za ova djela, po službenoj dužnosti ili na zahtjev bilo kojeg entitetskog suda ili suda Distrikta Brčko."

Entitetski sudovi i pravosuđe Distrikta Brčko, na drugoj strani, u okviru nadležnosti određenih sopstvenim krivičnopravnim zakonodavstvom ${ }^{31}$ materijom poštovanja normi međunarodnog humanitarnog prava bave se u mjeri u kojoj su radnje kršenja normi humanitarnog prava predviđene materijalnopravnim normama njihovih krivičnih zakona ili u slučajevima kad im je nadležnost za postupanje delegirana od strane Suda $\mathrm{BiH}$. Na taj način su teške povrede pravila međunarodnog humanitarnog prava, pobrojane $\mathrm{u}$ ranije navedenim članovima Krivičnog zakona $\mathrm{BiH}$, formalnopravno posmatrano, usklađene sa inkriminacijama sadržanim u propisima međunarodnog humanitarnog prava, pri čemu je bitno naglasiti da je navedenim propisima, kada je riječ o implementaciji normi međunarodnog humanitarnog prava u pravni sistem $\mathrm{BiH}$, realizovano brisanje razlike između međunarodnog i unutrašnjeg sukoba, jer je predviđena primjena normi unutrašnjeg prava u odnosu na obe vrste sukoba ${ }^{32}$, čime je ispoštovan ra-

31 Oba entiteta, kao i Distrikt Brčko, imaju sopstvene krivične i zakone o krivičnom postupku, kao i zakone o sudovima.

32 Vidi odredbe, npr o krivičnom djelu ratnog zločina protiv civilnog stanovništva iz čl. 173. $\mathrm{KZBiH}$, u kome stoji „Ko kršeći pravila međunarodnog prava za vrijeme rata, oružanog 
nije objašnjen princip primjene normi međunarodnog humanitarnog prava i na nemeđunarodne oružane sukobe.

\subsection{Princip zabrane retroaktivne primjene krivičnopravnih normi}

Opšteprihvaćen princip nullum crimen sine lege, nulla poena sine lege (nema zločina bez zakona, nema kazne bez zakona), koji je kao takav bio zastupljen i u zakonodavstvu bivše SFRJ, preuzet je i u krivičnopravno zakonodavstvo $\mathrm{BiH}$ i njenih entiteta, kao i Distrikta Brčko. Obavezujući pravni osnov se nalazi u ranije citiranim odredbama Dejtonskog sporazuma o obavezama $\mathrm{BiH}$ na poštovanje standarda sadržanih u 16 međunarodnih dokumenata kojima se štite osnovna ljudska prava i slobode. Tako je, u članu 7. st. 1. Evropske konvencije o zaštiti ljudskih prava i osnovnih sloboda, naglašeno da „niko neće biti smatran krivim za krivično djelo zbog činjenja ili propuštanja, koje nije predstavljalo krivično djelo po unutrašnjem ili međunarodnom pravu u trenutku kada je izvršeno. Isto tako, ne može se izreći strožija kazna od one koja je bila propisana u vrijeme izvršenja krivičnog djela."Usvajanjem ovog načela garantuje se pojedincima da mogu biti suđeni i kažnjeni samo za ono ponašanje koje je zakonom u vrijeme počinjenja bilo predviđeno kao krivično djelo. Činjenica da djelo i krivičnopravna sankcija mogu, osim zakonom, biti propisani i medunarodnim pravom, ne umanjuje vrijednost principa zakonitosti, ukoliko je nacionalno zakonodavstvo usklađeno sa međunarodnim konvencijama koje predstavljaju izvor medunarodnog krivičnog prava. Pritom je neophodno naglasiti da se pod izvorima međunarodnog krivičnog prava podrazumijevaju primarno izvori u pisanoj formi (ugovori, npr. tradicionalno „haško" i ,ženevsko pravo” sadržano u istoimenim konvencijama), kao i običajno pravo, $s$ tom razlikom što se međunarodno običajno pravo ${ }^{33}$ ne primjenjuje da bi se inkriminisala neka radnja, većda bi se utvrdila sadržina i domet nekog međunarodnog pravila. Zahtjevi načela zakonitosti ne sprečavaju suđenje ili kažnjavanje bilo kojeg lica za radnju koja je u vrijeme kada je izvršena predstavljala krivično djelo u skladu sa opštim načelima međunarodnog prava. Ovaj princip definisan je na identičan način u čl.7. st. 2. EKLJP, čl. 15. st. 2. Pakta o građanskim i političkim pravima, odnosno čl. 49. st. 2. Povelje o osnovnim pravima u Evropskoj uniji, aktima koji, iako se ne smatraju dijelom međunarodnog humanitarnog prava, ipak predstavljaju pravno obavezujuće izvore me-

sukoba ili okupacije naredi ili učini koje od ovih djela..." (potcrtala Lj. Mijović).

33

Za postojanje pravila običajnog prava potrebno je prisustvo dva elementa: praksa države (usus) i svijest da je takva praksa neophodna, zabranjena ili dozvoljena u zavisnosti od prirode pravila, kao pravni element (opinio iuris sive necessitatis). 
đunarodnog prava.Pored ovih formalnih izvora, neophodno je imati na umu i opšta načela međunarodnog prava, pod kojim podrazumijevamo načela preuzeta iz nacionalnih pravnih sistema koja se primjenjuju na međunarodnom nivou (npr. načelo zakonitosti, pretpostavka nevinosti, jednakost strana, načelo poštovanja ljudskog života, dostojanstva, imovine i dr.), uslijed čega se, primjera radi, krivična djela krađe ili ubistva smatraju krivičnim djelima po opštim načelima međunarodnog prava, čak i kada ne bi postojala inkriminacija u nacionalnom zakonodavstvu. Do usvajanja Rimskog statuta najvećom manom međunarodnog prava smatralo se neodređivanje sankcija za međunarodno kažnjiva djela, u kojem slučaju se posezalo za primjenom opšteg načela legaliteta. Usvajanjem istog Statuta uspostavljena je pravna sigurnost u pogledu obaveznosti potpunog primjena međunarodno-pravnih normi.

Kada je u pitanju zabrana retroaktivnosti primjene krivičnopravnih normi, ista je predviđena odredbama međunarodnog humanitarnog prava u više izvora. Tako je Ženevskom konvencijom (IV) o zaštiti građanskih lica za vrijeme rata u čl. 67. određeno da „sudovi mogu da primjenjuju samo zakonske propise donijete prije izvršenja krivičnog djela i koji su u skladu s opštim načelima prava, naročito u pogledu načela srazmjernosti kazne”, dok se u Dopunskom protokolu uz Ženevske konvencije o zaštiti žrtava medunarodnih oružanih sukoba (Protokol I, 1977. god.), članom 75. stav 4. tačka (c) predviđa da „niko ne može biti optužen ili osuđen za krivično djelo za bilo koju radnju ili propust koji ne predstavljaju krivično djelo prema nacionalnom ili međunarodnom pravu pod koje je on potpadao u momentu učinjenog djela”, te da se „ne može izreći teža kazna od kazne koja je bila primjenjiva u vrijeme kada je krivično djelo bilo izvršeno". Odredbe Rimskog statuta iz 1998. godine takođe predviđaju primjenu načela zakonitosti, odnosno zabrane retroaktivnosti (čl. 22 - 24.), iako primjenu ovih načela vežu samo za djelatnost Međunarodnog krivičnog suda.

S obzirom na to da su načelo zakonitosti i zabrana retroaktivne primjene krivičnopravnih propisa bili prisutni i u pravnom sistemu bivše SFRJ, isti principi su preuzeti i u zakonodavstvo $\mathrm{BiH}$, gdje je Krivičnim zakonom $\mathrm{BiH}$, načelo zakonitosti predviđeno članom 3. st. $1 .{ }^{34}$, a zabrana retroaktivne primjene istim članom, st.2. ${ }^{35}$. Formalnopravno, moglo bi se konstatovati da su u pogledu primjene navedenih principa u pravni sistem $\mathrm{BiH}$ u potpunosti implementirane odredbe koje

Tekst odredbe: „Krivična djela i krivičnopravne sankcije propisuju se samo zakonom.“

Tekst odredbe:„Nikome ne može biti izrečena kazna ili druga krivičnopravna sankcija za djelo koje, prije nego što je učinjeno, nije bilo zakonom ili međunarodnim pravom propisano kao krivično djelo i za koje zakonom nije bila propisana kazna." 
se tiču kako normi međunarodnog humanitarnog prava, tako i propisa o ljudskim pravima u cjelini, iako se isto ne može konstatovati i u odnosu na sudsku praksu Suda BiH, uslijed čega je Evropski sud za ljudska prava u presudi Maktouf i Damjanović protiv $\mathrm{BiH}^{36}$ ustanovio povredu člana 7. Evropske konvencije.

\subsection{Princip univerzalne jurisdikcije}

Princip univerzalne jurisdikcije u slučaju izvršenja krivičnih djela koja se odnose na teške povrede normi međunarodnog humanitarnog prava podrazumijeva obavezu svih država potpisnica da osiguraju normama svog zakonodavstva izvođenje osumnjičenih počinilaca navedenih djela pred sopstvene sudove, bez obzira čiji državljani mogu biti takva lica ili njihovo izručenje, ako neka druga zemlja posjeduje pravni interes i dokaze protiv istog lica (princip aut dedere, aut punire). Kada je u pitanju implementacija principa univerzalne jurisdikcije, u Krivičnom zakonu BiH je članom 9.,st. 1. (c) predviđena primjena krivičnog zakonodavstva $\mathrm{BiH}$ na svakog „ko van njene teritorije počini krivično djelo koje je $\mathrm{BiH}$ obavezna kažnjavati prema propisima međunarodnog prava, međunarodnih ili međudržavnih ugovora”, a slično rješenje sadrže i entitetski i Krivični zakon Distrikta Brčko.

Kada je u pitanju druga strana principa univerzalne jurisdikcije, odnosno mogućnost izručenja lica osumnjičenog ili osuđenog za izvršenje međunarodnog krivičnog djela drugoj državi u cilju vođenja krivičnog postupka ili izvršenja izrečene kazne (ekstradicija), pravni osnov u međunarodnom pravu predstavljaju Principi OUN o međunarodnoj saradnji u otkrivanju, hapšenju, ekstradiciji i kažnjavanju krivaca za ratne zločine i zločine protiv čovječnosti iz 1983. godine, a koji principi obezbjeđuju gonjenje i kažnjavanje takvih lica, bez obzira gdje se nalazila.

$\mathrm{U} \mathrm{BiH}$ proces ekstradicije regulisan je Zakonom o međunarodnoj pravnoj pomoći u krivičnim stvarima ${ }^{37}$, čijim je odredbama predviđeno da će do ekstradicije doći ako (čl. 34.) lice čije se izručenje traži nije državljanin $\mathrm{BiH}$; ako se ne radi o licu koje uživa azil u $\mathrm{BiH}$; ako djelo nije izvršeno na teritoriji $\mathrm{BiH}$, protiv $\mathrm{BiH}$ ili njenog državljanina; ako je djelo inkriminisano u zakonu države koja traži izručenje, kao i u zakonu $\mathrm{BiH}$; ako se ne radi o političkom ili vojnom krivičnom djelu; ako nije nastupila zastara; ako se ne radi o već presuđenoj stvari; ako je utvrđen identitet lica koje se traži; ako postoji pravosnažna presuda, odnosno

36 Vidjeti presudu ESLJP Maktouf i Damjanović protiv BiH , br. 2312/08i 34179/08, 18. juli 2013. godine

37 Službeni glasnik BiH, br. 53/2009 i 58/2013. 
dovoljno dokaza za osnovanu sumnju; ako se izručenje ne traži zbog gonjenja ili kažnjavanja zasnovanog na rasi, polu, nacionalnosti, vjeri ili političkom uvjerenju, te ako licu ne prijeti smrtna kazna u slučaju izručenja. Molba za izručenje se podnosi diplomatskim putem, ili, u slučaju da postoji međunarodni ugovor, direktno Ministarstvu pravde $\mathrm{BiH}$, koje molbu prosljeđuje Tužilaštvu $\mathrm{BiH}$, nakon čega se dostavlja Sudu $\mathrm{BiH}$ na odlučivanje. Na osnovu predviđenog zakonskog rješenja, može se konstatovati da je domaća legislativa usklađena sa zahtjevima principa univerzalne jurisdikcije sadržanim u normama međunarodnog prava, iako bi bilo uputno da se posebnim zakonskim odredbama naglasi određenje ove jurisdikcije u odnosu na djelakoja predstavljaju teške povrede normi međunarodnog humanitarnog prava, jer se na način na koji je trenutno određena ona uočava tumačenjem opštih odredaba koje se tiču nadležnosti, a koje smo citirali $\mathrm{u}$ gore navedenom tekstu.

\subsection{Komandna odgovornost i odgovornost za djela učinjena po naređenju}

Iako primjenjivana na različite načine, doktrina komandne odgovornosti je svoje pravno uobličavanje u međunarodnom pravu započela Haškim konvencijama iz 1907. godine. Rimskim statutom ova odgovornost (čl 28.) predviđena je kao odgovornost vojnog zapovjednika za krivična djela koja su izvršile snage pod njihovom neposrednom komandom i kontrolom, i/ili ukoliko su snage pod njegovom neposrednom komandom i kontrolom izvršile krivično djelo uslijed propusta zapovjednika da izvrši odgovarajuću kontrolu nad tim snagama. Odgovornost zapovjednika postoji ukoliko je znao, ili je prema okolnostima slučaja morao da zna da su snage izvršile ili da su spremne da izvrše djelo, kao i kada je zapovjednik propustio da preduzme sve neophodne i razumne mjere u njegovoj moći kako bi spriječio izvršenje tih krivičnih djela.

Komandna odgovornost u legislativi $\mathrm{BiH}$ predviđena je čl. 180. KZ BiH, po kome se nadređeni smatra odgovornim za krivična djela ${ }^{38}$ počinjena od strane njemu podređenih lica samo ukoliko je znao ili je mogao znati da se lice sprema počiniti ili je već počinio takvo djelo, pri čemu je kao nadređeni propustio da preduzme nužne i razumne mjere da spriječi počinjenje djela, odnosno da učinilac djela bude kažnjen. Ovaj oblik krivične odgovornosti, očito je, postoji samo u vidu nečinjenja.

38 Za djela genocida, zločina protiv čovječnosti, ratnog zločina protiv civilnog stanovništva, ratnog zločina protiv ranjenih i bolesnih, ratnog zločina protiv ratnih zarobljenika, protivpravnog ubijanja i ranjavanja neprijatelja, protivpravnog oduzimanja stvari od ubijenih i ranjenih na ratištu i povrede zakona i običaja rata. 
Na drugoj strani, kad je riječ o izvršenju djela po naredbi pretpostavljenog, već je Sud u Nirnbergu decidno utvrdio da postupanje po naredbi ne oslobađa potčinjenog od krivične odgovornosti. Dopunski protokol br. 1 na Ženevske konvencije iz 1977. godine (član 86., st.2.) uveo je ovu ustanovu kao osnov krivične i disciplinske odgovornosti, dok je Statutom MKSJ postojanje naredbe bilo predviđeno kao olakšavajuća okolnost po direktnog počinioca djela. Rimski statut predviđa oslobađanje počinioca od odgovornosti samo ukoliko nije znao, niti mogao znati da je naredba protivzakonita. U BiH odgovornost za krivično djelo učinjeno po naređenju nadređenog predviđena je članom 246.ww. KZ BiH, u kome stoji da „nema krivičnog djela ako njegova zakonska obilježja ostvari podređeni po naređenju nadređenog, a to naređenje dato je u okviru službene dužnosti, osim ako se naređenje odnosi na činjenje genocida, ratnog zločina, zločina protiv čovječnosti ili drugog krivičnog djela za koje se može izreći kazna zatvora deset godina ili teža kazna, ili ako je očigledno da se izvršenjem naređenja čini krivično djelo, koja se odredba može smatrati usklađenom sa normama međunarodnog prava.

\subsection{Neizvršenje naređenja}

Za oružane snage kao jedan od najbitnijih principa njihovog organizovanja vezuje se subordinacija, odnosno disciplina zasnovana na poslušnosti u provođenju naređenja. S druge strane, naređenja koja se izdaju ne moraju, i nažalost, često to i nisu, uvijek biti zakonita, a ni u skladu sa međunarodnim humanitarnim pravom. U vezi s tim, razlikujemo neizvršavanje zakonitih naređenja, u kojem slučaju govorimo o krivičnom djelu odbijanja izvršenja naređenja i neizvršavanje nezakonitih naređenja, u kojem slučaju govorimo o obavezi svakog podređenog pripadnika oružanih snaga, da u skladu sa odredbama međunarodnog humanitarnog prava odbije izvršenje naređenja kojim bi došlo do potvrde normi tog istog prava.

Neizvršenje ili odbijanje izvršenja naređenja je, kao krivično djelo protiv Oružanih snaga $\mathrm{BiH}$, predviđeno članom 246 (a), gdje se u st. 1. navodi da će vojno lice koje ne izvrši ili odbije da izvrši naređenje nadređenog u vezi sa službom, pa zbog toga nastupi nemogućnost obavljanja ili otežano obavljanje službe ili opasnost po život ljudi ili imovinu velike vrijednosti, biti kažnjeno kaznom zatvora do pet godina, dok će (st. 2.) vojno lice koje se protivi stražaru, patroli, službenom ili drugom vojnom licu u sličnoj službi dok obavljaju svoju dužnost, kao i vojno lice koje ne posluša njihov poziv ili ne izvrši ili odbije da izvrši njihovo naređenje, biti kažnjeno novčanom ili kaznom zatvora do jedne godine. U st. 3. predviđa se da će se počinilac, ukoliko su krivičnim djelom iz st. 1 i 2 . prouzrokovane izra- 
zito teške posljedice za vojnu službu, kazniti kaznom zatvora od dvije do osam godina. Ovo je, kako je to već pomenuto, slučaj kada se radi o odbijanju izvršenja zakonitog naređenja, i tiče se dakle, krivičnog djela kojim se ugrožava disciplina, ali i životi ljudi i imovina, koji mogu doći u opasnost neizvršenjem naređenja, i zapravo je sama ta posljedica bitno obilježje djela. Potrebno je, dakle, da nastupi posljedica koja se sastoji u ugrožavanju ljudskih života i imovine, kako bi djelo uopšte bilo smatrano počinjenim.

Što se tiče drugog pomenutog slučaja, neizvršavanja nezakonitih naređenja (obavezi svakog podređenog pripadnika oružanih snaga, da u skladu sa odredbama međunarodnog humanitarnog prava odbije izvršenje naređenja kojim bi došlo do povrde normi tog istog prava), isti slučaj je regulisan stavom 5. u kome se kaže da se počinilac krivičnog djela iz st. 1. i 2. ovog člana, koji je bio izazvan protivzakonitim ili nepravilnim postupanjem nadređenog, stražara, patrole, službenog ili drugog vojnog lica, može blaže kazniti ili osloboditi kazne. U skladu sa navedenim odredbama je i čl. 17. Zakona o službi u oružanim snagama $\mathrm{BiH}^{39} \mathrm{u}$ kome stoji da su vojna lica dužna poštovati naređenja, izuzev ukoliko se radi o naređenju koje ima obilježja krivičnog djela, a ukoliko je takvo naređenje izdato, vojna lica su obavezna da o tome obavijeste starješinu nadređenu onom koji je izdao takvo naređenje, što je takođe odredba za koju se može reći da je usklađena sa normama međunarodnog humanitarnog prava.

\subsection{Zaštita znaka i amblema Crvenog krsta}

Odredbama Dodatnih protokola br. III na Ženevske konvencije ${ }^{40}$, države potpisnice preuzele su obavezu ne samo da se uzdrže od bilo kojih akata koji bi značili povredu zaštitnih odredaba, već i da domaćom legislativom ustanove adekvatan stepen zaštite znaka i amblema Crvenog krsta. Ova obaveza je od strana potpisnica preuzeta i smatra se važećom kako za vrijeme trajanja oružanog sukoba, tako i u vrijeme mirnog stanja.

Implementacija ove zaštite u pravni sistem BiH izvršena je članom 184. st.1. KZ $\mathrm{BiH}$ u kojem se predviđa da će se lice koje zloupotrijebi ili neovlašteno nosi zastavu ili znak Organizacije ujedinjenih naroda ili znakove ili zastave Crvenog krsta

39 Službeni glasnik BiH, br. 88/05.

40 Ženevske konvencije za poboljšanje položaja ranjenika i bolesnika u oružanim snagama u ratu, Ženevske konvencije za poboljšanje položaja ranjenika, bolesnika i brodolomnika, Ženevske konvencije o zaštiti građanskih lica u vrijeme oružanih sukoba, od 12. augusta 1949. godine i Dopunskog protokola I i II uz Ženevske konvencije, od 10. juna 1977. godine. 
ili znakove koji njima odgovaraju, ili pak druge priznate međunarodne znakove kojima se obilježavaju određeni objekti radi zaštite od vojnih djelovanja, kazniti novčanom ili kaznom zatvora do tri godine, a da će (st.2.) onaj ko krivično djelo iz stava 1. ovog člana učini za vrijeme ratnog stanja ili neposredne ratne opasnosti biti kažnjen kaznom zatvora od šest mjeseci do pet godina. Dopunom ovog člana mogu se smatrati i odredbe Zakona o upotrebi i zaštiti znaka crvenog krsta/ križa i naziva društva Crvenog krsta/križa $\mathrm{BiH}^{41}$, u vezi s kojim je interesantno navesti odredbu člana 24. koji predviđa kažnjavanje lica koje namjerno izvrši, ili izda naređenje za izvršenje djela koje za posljedicu ima smrt ili koje uzrokuje tešku tjelesnu povredu ili povredu zdravlja pripadnika neprijateljskih snaga, zloupotrebom znaka crvenog krsta/križa, u kojem slučaju će se isto djelo smatrati za ratni zločin. Isti član pojam „zloupotreba” određuje kao „apeliranje na neprijateljske snage, $u$ namjeri da se neprijatelj obmane i uvjeri da ima pravo ili obavezu da dobije, odnosno pruži zaštitu koju predviđaju pravila međunarodnog humanitarnog prava", što se može smatrati djelom perfidije.

\subsection{Zaštita lica u zatočeništvu ili pod vlašću suprotne strane (Ratni zaroblje- nici i civili)}

S obzirom na to da je status ratnih zarobljenika, njihova prava i obaveze detaljno regulisan odredbama Treće Ženevske konvencije i Dodatnog protokola I, pretpostavka je da nacionalna zakonodavstva treba da slijede tu detaljnu regulaciju usvajanjem identičnog obima zaštite, odnosno da osiguraju da ratni zarobljenici budu tretirani kao osobe koje su lišene slobode iz sigurnosnih razloga i ratne potrebe izbacivanja što većeg broja pripadnika neprijateljske oružane sile iz stroja, a ne kao počinioci krivičnih djela. Primjena pravila međunarodnog ratnog prava u slučaju oružanog sukoba upravo i ide u tom pravcu - da se, izbijanjem oružanog sukoba u jednoj zemlji (nemeđunarodno oružanog sukoba), pripadnicima neprijateljskih, npr. pobunjeničkih snaga, pruži status ratnog zarobljenika i obezbijedi human tretman u smislu da ne budu tretirani kao počinioci krivičnog djela kao što su npr. krivična djela protiv države ili terorizma. Kada su u pitanju civili, osobito žene i djeca, na međunarodnom planu je Četvrtom Ženevskom konvencijom precizno regulisana zaštita ove kategorije lica, u pravcu postizanja što je moguće manje patnji civila, odnosno onih koji u oružanom sukobu ne učestvuju.

$\mathrm{Na}$ području $\mathrm{BiH}$ status ovih kategorija lica regulisan je posredno, posebnom glavom (XVII) KZBiH koja se tiče krivičnih djela protiv čovječnosti i vrijednosti 
zaštićenih međunarodnim pravom. Tako je članom 175. KZBiH predviđeno da će se lice koje prema ratnim zarobljenicima naredi ili učini ubistva, mučenja, nečovječno postupanje, biološke, medicinske ili druge naučne eksperimente, uzimanje tkiva ili organa radi transplantacije, nanošenje patnji, ozljeda tijela, povrede zdravlja ili ih pak prisili na službu u neprijateljskim oružanim snagama, te liši prava na pravično i nepristrasno suđenje, kazniti kaznom zatvora od najmanje deset godina. Krivičnim zakonom je zabranjeno i neopravdano odgađanje repatrijacije ratnih zarobljenika ukoliko je došlo okončanja oružanog sukoba (čl. 182.), za koje je zaprijećena kazna zatvora od šest mjeseci do pet godina. Kada je riječ o zaštiti civilnih lica, ista kazna zaprijećena je članom 173. st.1. KZBiH u odnosu na svako lice koje kršeći pravila međunarodnog prava za vrijeme rata, oružanog sukoba ili okupacije naredi ili izvrši ratni zločin protiv civilnog stanovništva u vidu napada na civilno stanovništvo, naselje, pojedine civilne osobe ili osobe onesposobljene za borbu, a taj je napad izazvao smrt, tešku tjelesnu ozljedu ili teško narušavanje zdravlja ljudi, ili pak naredi ili izvrši napad kojim se ozljeđuje civilno stanovništvo, odnosno neselektivni napad (st.1. (a) i (b)). Ratnim zločinom protiv civilnog stanovništva smatraće se, prema trećem stavu istog člana (st.1. (c).) i naredba ili čin ubijanja, mučenja, nečovječnog postupanja, biološki, medicinski ili drugi naučni eksperimenti, uzimanje tkiva ili organa radi transplantacije, nanošenje patnji ili povreda tjelesnog integriteta ili zdravlja, te (st. 1 . (d)) raseljavanje i prisilno odnarođavanje/prevođenje na drugu vjeroispovijest. Naredba ili izvršenje prisilnog seksualnog odnosa, prisiljavanja na prostituciju, zastrašivanje i terror, uzimanje talaca, kolektivno kažnjavanje, protupravno odvođenje u koncentracione logore i druga protivzakonita zatvaranja, oduzimanje prava na pravično i nepristrasno suđenje, prisiljavanje na službu u neprijateljskim oružanim snagama ili u neprijateljskoj obavještajnoj službi ili upravi, te prisiljavanje na prinudni rad, izgladnjivanje stanovništva, konfiskacija imovine, pljačkanje imovine stanovništva, protivpravno, samovoljno i vojnim potrebama neopravdano uništavanje ili prisvajanje imovine u velikim razmjerama, uzimanje nezakonite i nesrazmjerno velike kontribucije i rekvizicije, smanjenje vrijednosti domaće novčane jedinice ili protuzakonito izdavanje novca (st. 1. (e) i (f)), takođe se smatraju ratnim zločinom protiv civilnog stanovništva.

\subsection{Zaštita ranjenika i bolesnika}

Zaštita ranjenika, bolesnika i brodolomnika (predviđena Prvom i Drugom Ženevskom konvencijom, zavisno od tog da li je riječ o suvozemnom ili pomorskom ratu) obavezuje strane u sukobu na brigu i zaštitu ranjenih i bolesnih pripadnika oružanih snaga, osoblja koje se o njima stara, kao i objekata u kojima 
su smješteni i opreme koja se koristi za njihove potrebe, dok je implementacija ovih odredaba izvršena u KZBiH posredno, regulisanjem ratnog zločina protiv bolesnika i ranjenika (čl. 174. KZBiH) kao krivičnog djela kojim se licu koje kršeći pravila međunarodnog prava za vrijeme rata ili oružanog sukoba, prema ranjenicima, bolesnicima, brodolomnicima ili sanitetskom ili vjerskom osoblju naredi ili izvrši ubistvo, mučenje, nečovječno postupanje, biološke, medicinske ili druge naučne eksperimente, uzimanje tkiva ili organa radi transplantacije, nanošenje patnji ili ozljeda tijela ili povreda zdravlja, te naredi ili izvrši protivpravno, samovoljno, vojnim potrebama neopravdano uništavanje ili prisvajanje u velikim razmjerima materijala, sredstava sanitetskog transporta i zaliha sanitetskih ustanova ili jedinica, prijeti kaznom od najmanje deset godina zatvora.

\section{8. Zaštita objekata}

Kao nužna posljedica svakog oružanog sukoba, pored ljudskih žrtava, javlja se i uništavanje objekata u odnosu na koje postoji niz zaštitnih normi međunarodnog humanitarnog prava. Tu se, prije svega, podrazumijeva zabrana napada na sanitetske i vjerske objekte, kao i osoblje koje se u njima nalazi. Kada je u pitanju zaštita od napada na medicinsko i vjersko osoblje, opšti stav zabrane napada sadržan je u Protokolu I čl.12., a kad je riječ o zaštiti sanitetskih i vjerskih objekata neophodno je pomenuti odredbe sadržane u Haškoj konvenciji o zaštiti kulturnih dobara u slučaju oružanog sukoba, kao i odredbe Protokola I (čl.53.) i Protokola II (čl.16.). U ovom kontekstu potrebno je naglasiti i obavezu zaštite objekata u kojima se vrše opasne djelatnosti ili čuvaju opasne materije. Odredbama člana 56. Dodatnog Protokola I regulisana je obaveza uzdržavanja od napada na objekte koji sadrže opasne materije ili se bave opasnom djelatnošću, čak i u slučaju da se radi o objektima, odnosno djelatnostima koje služe u vojne svrhe. Istu odredbu sadrži i Dodatni protokol II u čl. 15. Zaštita kulturnih dobara sadržana je u Dodatnim protokolima, kao i u Konvenciji o zaštiti kulturnih dobara u slučaju oružanog sukoba iz 1954. godine, iako je u Konvenciji riječ o potrebi preduzimanja mjera zaštite kulturnih dobara u periodu mirnog stanja, odnosno mjeru prevencije u slučaju oružanog sukoba. Zaštićene zone i područja su predmet regulisanja čitavog niza odredaba međunarodnog humanitarnog prava, od čl. 23. Prve konvencije i čl. 14. Četvrte konvencije, do čl. 15. Četvrte konvencije koji reguliše status neutralnih zona i čl. 59. i 60. Dodatnog protokola I koji regulišu položaj nebranjenih područja i demilitarizovanih zona.

Odredbama KZBiH štite se (čl. 173. st.2. (a), (b) i (c)) objekti posebno zaštićeni međunarodnim pravom ili opšteopasni objekti i postrojenja kao što su brane, nasipi i nuklearne elektrane; civilni objekti koji su pod posebnom zaštitom me- 
đunarodnog prava, nebranjena mjesta i demilitarizovane zone; dok se u čl. 179. (st. 2 (b)) zabranjuje bezobzirno razaranje gradova, naselja ili sela ili pustošenje koje nije opravdano vojnim potrebama; (st. 2. (c)) napad ili bombardovanje bilo kojim sredstvima nebranjenih gradova, sela, nastambi ili zgrada; te (st.2. (d)) pljenidba, uništavanje ili namjerno oštećenje ustanova namijenjenih vjerskim, dobrotvornim ili obrazovnim potrebama, nauci i umjetnosti, istorijskih spomenika i naučnih i umjetničkih djela.

\section{9. Sredstva i metodi ratovanja}

Nedozvoljenim sredstvima i metodama ratovanja smatraju se sva ona sredstva i metode koja uzrokuju nepotrebne patnje, ili se odnose na neselektivne napade. Zaštitne norme međunarodnog humanitarnog prava u ovoj oblastiveć se mogu smatrati dijelom običajnog prava, mada su i formalnopravno regulisane odredbama Dodatnog protokola I ${ }^{42}$. Kako je o neselektivnim napadima već ranije bilo riječi, ovom prilikom ćemo samo naglasiti postojanje zabrane korištenja (čl. 179. KZBiH, st. 2. (a)) bojnih otrova ili drugih ubojitih sredstava s ciljem izazivanja nepotrebne patnje, pod kojima bi se morala podrazumijevati i zabrana neselektivnog, tzv. „slijepog oružja” čije se dejstvo ne može potpuno kontrolisati prilikom upotrebe.

\section{Obaveza osnivanja nacionalnog društva Crvenog krsta/križa/polumjeseca}

Uloga Međunarodnog komiteta Crvenog krsta precizno je definisana, kako paketom Ženevskih konvencija, tako i samim Statutom Pokreta, koji istovremeno predviđa i obavezu svih država da osnuju nacionalno društvo Crvenog krsta/ križa/polumjeseca. Neposredno nakon oružanog sukoba, s obzirom na entitetsku podjelu, postojala su entitetska društva Crvenog krsta/križa/polumjeseca, što je otežavalo jedinstvenu pomoć svim ugroženim kategorijama lica. Pet godina nakon potpisivanja Dejtonskog mirovnog sporazuma, $\mathrm{BiH}$ je dobila Društvo Crvenog krsta/križa/polumjeseca $\mathrm{BiH}$, čime je savladana prva prepreka na putu do punopravnog učlanjenja u Međunarodni pokret Crvenog krsta/križa i Crvenog polumjeseca. U Sarajevu je 15. decembra 2000. godine održana konstitutivna sjednica Društva Crvenog krsta/križa Bosne i Hercegovine, a odlučujuću ulogu u postizanju sporazuma o ujedinjenju dvaju entitetskih organizacija imala je septembarska odluka Vijeća ministara $\mathrm{BiH}$ da prizna samo jednu jedinstvenu

${ }_{42} \quad$ Čl. 35., 51., 55. i 58. 
organizaciju Crvenog krsta/križa/polumjeseca za cijelu zemlju. Ovim je $\mathrm{BiH}$ ispunila najvažniji preduslov za uključenje u Međunarodni pokret Crvenog krsta/ križa i Crvenog polumjeseca koji trenutno obuhvata nacionalne organizacije iz 190 zemalja svijeta.

\section{Zaključak}

Implementacija normi međunarodnog humanitarnog prava je obaveza svih država potpisnica međunarodnih ugovora iz ove oblasti. U BiH ta obaveza je naglašena već samim Mirovnim sporazumom, Aneksom VI, čl.1. kojim se BiH obavezala na poštovanje najvišeg nivoa ljudskih prava i sloboda predviđenih nizom međunarodnih dokumenata, uključujući i Ženevske konvencije i pripadajuće protokole. Imajući na umu specifičnost državnopravnog uređenja $\mathrm{BiH}$, proces implementacije međunarodnog humanitarnog prava u unutrašnji pravni sistem pokazao se kao dugotrajan proces, s obzirom na specifično postavljenu zakonodavnu nadležnost i međunarodnopravni subjektivitet $\mathrm{BiH}$. Kao veoma aktivan činilac u procesu implementacije, i uopšteno, diseminacije međunarodnog humanitarnog prava pokazao se Međunarodni pokret Crvenog krsta/križa i Crvenog polumjeseca, iako bi saradnja organa vlasti i Pokreta (Komiteta - MKCK) morala biti intenzivnije usmjerena prvenstveno na edukaciju članova zakonodavnih tijela i pripadnika Oružanih snaga $\mathrm{BiH}$, a onda i edukaciju pravničke javnosti i studentske populacije.

Drugim značajnim segmentom implementacije izvjesno treba smatrati i domaće pravosuđe, koje je, kada je riječ o procesuiranju krivičnih djela za kršenje normi međunarodnog humanitarnog prava, bilo pomalo zatečeno prosljeđivanjem predmeta od strane MKSJ u Hagu. Formalnopravno posmatrano, radilo se o primjeni domaćih pravnih normi čije je izvorište bilo u međunarodnom pravu, uslijed čega je u praksi došlo do nesnalaženja domaće judikature, iako je to bio više problem subjektivne prirode, nego krivičnoprocesnog zakonodavstva.

Još jedan od značajnih, takođe subjektivnih problema, počiva u činjenici da, bez obzira na postojanje normi kojima se implementira međunarodno humanitarno pravo u manjoj ili većoj mjeri, uvijek postoji jaz između formalnopravnog i stvarnog stanja, zbog čega je neophodno insistirati ne samo na izmjeni ili dopuni zakonske regulative, već prvenstveno na provođenju postojeće. To podrazumijeva mnogo šire pretpostavke stvarne implementacije međunarodnog humanitarnog prava, jer se tiče uspostave pravne države, principa pravne sigurnosti, efikasnog provođenja zakona i sankcionisanja za nepoštivanje istih zakona. 


\section{IMPLEMENTATION OF INTERNATIONAL HUMANITARIAN LAW IN THE LEGAL SYSTEM OF BOSNIA AND HERZEGOVINA}

Summary: The paper deals with the implementation of the rules of international humanitarian law in the legal system of Bosnia and Herzegovina, as well as the manner in which this implementation has been carried out.

In this paper the Author analyzes the most important principles of international humanitarian law, from the principle of non-retroactivity of criminal law and universal jurisdiction, to the protection of certain categories of persons and objects, the use of protective signs in armed conflict, the command responsibility and the duty to disobey manifestly illegal orders.

Key words: International Humanitarian Law, non-international armed conflict, implementation, Geneva Conventions, Additional Protocols 